\title{
LAPTM5 wt Allele
}

National Cancer Institute

\section{Source}

National Cancer Institute. LAPTM5 wt Allele. NCI Thesaurus. Code C150082.

Human LAPT M5 wild-type allele is located in the vicinity of 1 p35.2 and is approximately $25 \mathrm{~kb}$ in length. This allele, which encodes lysosomal-associated transmembrane protein 5 , plays a role in the modulation of both embryogenesis and hematopoietic cell differentiation. 